\title{
Prospection of Psychrotrophic Filamentous Fungi Isolated from the High Andean Paramo Region of Northern Ecuador: Enzymatic Activity and Molecular Identification
}

\author{
Stefan Alexander Brück 1,2,3 (D), Alex Graça Contato ${ }^{2}$ (D) Paul Gamboa-Trujillo 1,3, Tássio Brito de Oliveira 4 (D), \\ Mariana Cereia ${ }^{4}$ and Maria de Lourdes Teixeira de Moraes Polizeli ${ }^{2,4, * \mathbb{D}}$
}

1 Facultad de Ciencias Biológicas, Universidad Central del Ecuador, Quito 170403, Ecuador; brueck.stefan@gmail.com (S.A.B.); jpgamboa@uce.edu.ec (P.G.-T.)

2 Departamento de Bioquímica e Imunologia, Faculdade de Medicina de Ribeirão Preto, Universidade de São Paulo, Ribeirão Preto 14049-900, Brazil; alexgraca.contato@gmail.com

3 Facultad de Ingeniería Química, Universidad Central del Ecuador, Quito 170521, Ecuador

4 Departamento de Biologia, Faculdade de Filosofia, Ciências e Letras de Ribeirão Preto, Universidade de São Paulo, Ribeirão Preto 14050-901, Brazil; oliveiratb@yahoo.com.br (T.B.d.O.); macereia@ffclrp.usp.br (M.C.)

* Correspondence: polizeli@ffclrp.usp.br; Tel.: +55-16-3315-4680

\section{check for}

updates

Citation: Brück, S.A.; Contato, A.G.; Gamboa-Trujillo, P.; de Oliveira, T.B.; Cereia, M.; de Moraes Polizeli, M.d.L.T. Prospection of Psychrotrophic Filamentous Fungi Isolated from the High Andean Paramo Region of Northern Ecuador: Enzymatic Activity and Molecular Identification. Microorganisms 2022, 10, 282. https:// doi.org/10.3390/microorganisms10020282

Academic Editor: Carlos A. Jerez

Received: 29 October 2021

Accepted: 14 January 2022

Published: 26 January 2022

Publisher's Note: MDPI stays neutral with regard to jurisdictional claims in published maps and institutional affiliations.

Copyright: (C) 2022 by the authors. Licensee MDPI, Basel, Switzerland. This article is an open access article distributed under the terms and conditions of the Creative Commons Attribution (CC BY) license (https:// creativecommons.org/licenses/by/ $4.0 /)$.

\begin{abstract}
The isolation of filamentous fungal strains from remote habitats with extreme climatic conditions has led to the discovery of a series of enzymes with attractive properties that can be useful in various industrial applications. Among these, cold-adapted enzymes from fungi with psychrotrophic lifestyles are valuable agents in industrial processes aiming towards energy reduction. Out of eight strains isolated from soil of the paramo highlands of Ecuador, three were selected for further experimentation and identified as Cladosporium michoacanense, Cladosporium sp. (cladosporioides complex), and Didymella sp., this last being reported for the first time in this area. The secretion of seven enzymes, namely, endoglucanase, exoglucanase, $\beta$-D-glucosidase, endo- $1,4-\beta$-xylanase, $\beta$-D-xylosidase, acid, and alkaline phosphatases, were analyzed under agitation and static conditions optimized for the growth period and incubation temperature. Cladosporium strains under agitation as well as incubation for $72 \mathrm{~h}$ mostly showed the substantial activation for endoglucanase reaching up to $4563 \mathrm{mU} / \mathrm{mL}$ and xylanase up to $3036 \mathrm{mU} / \mathrm{mL}$. Meanwhile, other enzymatic levels varied enormously depending on growth and temperature. Didymella sp. showed the most robust activation at $8{ }^{\circ} \mathrm{C}$ for endoglucanase, $\beta$-D-glucosidase, and xylanase, indicating an interesting profile for applications such as bioremediation and wastewater treatment processes under cold climatic conditions.
\end{abstract}

Keywords: psychrotrophic fungi; high Andean Paramo; cold-adapted enzymes; bioprospecting

\section{Introduction}

The High Andean mountain region is marked by the paramo ecosystem, neotropical grassland covering mountainsides from 3500 up to $5000 \mathrm{~m}$ of altitude from Southern Venezuela, Colombia, Ecuador, and Northern Peru [1]. It is considered a hotspot of biodiversity mainly due to the fact of its high degree of endemic species adapted to extreme environmental conditions [2] such as intense radiation close to the equator line [3], nighttime temperatures close to the freezing point, and low availability of nutrients [4]. Fungi growing under these conditions tend to develop a psychrophilic or psychrotrophic profile, developing at $0{ }^{\circ} \mathrm{C}$ with optimum growth conditions of $\leq 15$ and $15-20{ }^{\circ} \mathrm{C}$, respectively $[5,6]$. This restricted ecological group has been found in terrestrial and marine environments from Polar Regions, deep water and marine sediments of the oceans, and high mountains [7-9].

The Paramo Region of South America is a vastly unexplored area in terms of soilderived microorganisms. Geospatial separation by Andean mountain chains creates a series of unique habitats, forcing microbes to adapt to a variety of given conditions, increasing 
the biological diversity with unique species within different paramo regions [10]. Most surveys of soil-borne fungi were conducted in the Colombian Paramo Region [11-13]. Information about fungi composition in Ecuadorian paramo soils is very scarce [14], and screenings for active enzymatic fungi with possible industrial applications have not been performed yet. Fungi isolated from the paramo can secrete cold-adapted enzymes [15], which are interesting in industrial procedures requiring low temperatures and employing energy to cool down the process. Nowadays, cold-active enzymes are mostly used in meat tenderization, food processing, flavoring, baking, brewing, cheese production, and animal feed $[16,17]$. They require low activation energies while showing during the meantime the highest activities, at low temperatures, of up to a 10-fold increase compared to mesophilic homologues [18], allowing for energy reduction [19], which might become increasingly important due to the tendency towards neutral carbon dioxide balances in times of global warming [20].

Enzymes can break down plant cell wall components, such as those of the cellulolytic system (endoglucanases, exoglucanases, and $\beta$-glucosidase), for efficient cellulose cleavage and of the xylanolytic system (mainly endoxylanase and $\beta$-xylosidase) for xylan breakdown to the level of reducing sugars. They are widely applied to biotechnological processes in areas such as the food industry, production of fuels, detergents, and biopulping [21-24]. Especially interesting for these cold-adapted enzymes are the treatment of wastewater and environmental bioremediation in countries with shallow temperatures due to the necessity of stable in situ applications without the need for heating [25,26].

Fungi further gain increasing importance as biofertilizers to improve crop yield. Given the broad range of climatic zones where crops are planted, biofertilizers must be equally adapted to these conditions including cold regions with generally lower productivity [6]. Cold adapted phosphatases can hydrolyze organic phosphate sources, which become assimilable by plant roots, improving their economic and ecologic growth, eliminating the need for chemical fertilizers $[9,27]$.

The present study, therefore, aimed to investigate filamentous fungi from paramo soil and optimize incubation conditions for optimal enzyme activity yield to analyze whether their extreme living conditions led to adapted enzymes of the carbon and phosphate cycle with possible interesting applications in the industry comparable to reported enzyme activities for mesophilic fungi. Unfortunately, soil-associated fungi of this region are poorly described and have never been analyzed for their enzymatic hydrolyzation capacities to the best of our knowledge.

\section{Materials and Methods}

\subsection{Sample Collection and Preparation}

Two sampling sites were established, each at two different altitudes within the grassland paramo (4000 $\mathrm{m}$ asl) and at the frontier between grassland paramo and superparamo (4150 $\mathrm{m}$ asl), lying on a lineal transect towards the peak of the volcano Northern Iliniza to guarantee similar climatic conditions and soil characteristics (Figure 1). Each sampling site was carefully selected for level ground, open vegetation in a good conservation state, and the absence of animal signs or human interference. Georeferencing with a GPS (Garmin, Olathe, KS, USA) was applied at each sampling site (Table S1). Then, $10 \mathrm{~cm}$ of topsoil was removed together with vegetation, and three soil samples were taken with sterile instruments, giving 12 samples. Data dataloggers (HOBO, Lakeville, MN, USA) were established at different altitudes to collect temperature data. Soil samples were analyzed by the Ecuadorian National Institute for Agricultural Research (INIAP) for organic matter $(\mathrm{OM})$, total nitrogen $(\mathrm{Nt})$, phosphorus, potassium, calcium magnesium (Olsen modified), and sulfur (calcium phosphate standard protocols). Conductivity was measured with water-saturated paste and $\mathrm{pH}$ in a soil-to-water ratio of 1:2.5. 

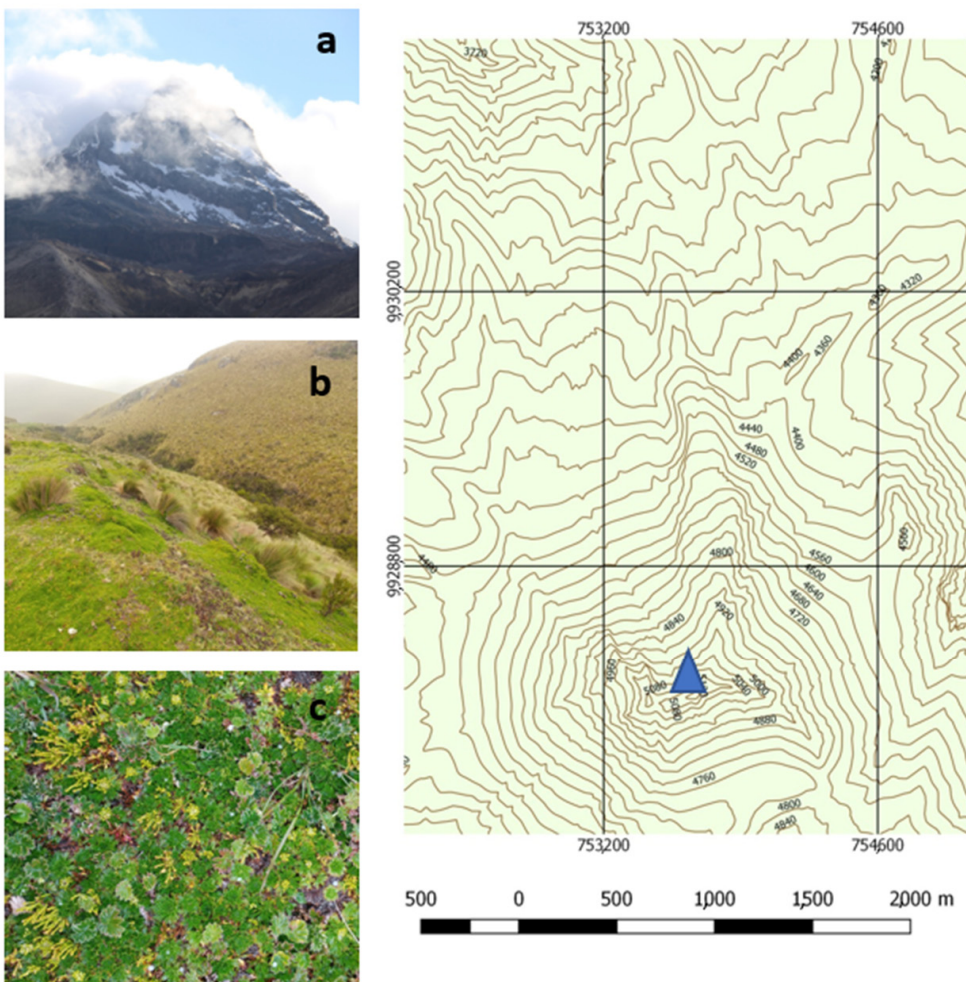

Figure 1. Sampling sites with a vision of the Illiniza north volcano (a); typical Andean grass paramo landscape (b); typical conserved paramo vegetation (c); the georeferenced linear transect of sampling towards the volcano peak (blue triangular) at the bottom left (d) (Source: (a-c) Author 2020; (d) modified from [28]).

Soil samples were diluted with sterile water at dilutions of $0.1 \mathrm{~g}$ in 10,100 , and $1000 \mathrm{~mL}$ with three replicates each, and $50 \mu \mathrm{L}$ of each dilution were distributed with a sterilized spreading rod on $10 \mathrm{~cm}$ Petri dish containing $12 \mathrm{~mL}$ of potato dextrose agar (PDA) (SigmaAldrich, Saint Louis, MO, USA) with streptomycin at $1 \mathrm{mg} / \mathrm{mL}$ (GM, London, UK). Then, Petri dishes were incubated for $48 \mathrm{~h}$ at $20^{\circ} \mathrm{C}$. After incubation, eight samples of clearly isolated and visibly round-shaped fungal colonies were picked with sterile toothpicks and transferred to a fresh PDA petri dish for cultivation.

For the growth assay, each fungus was picked with a sterile toothpick and inoculated at the center of a PDA Petri dish. Then dishes were incubated at 4,30 , and $40{ }^{\circ} \mathrm{C}$, respectively, for a total of 35 days. Growth was measured weekly in $\mathrm{cm}$ growth-diameter of the halo through the inoculation point.

\subsection{Fungal Strain Identification}

\subsubsection{DNA Extraction}

To obtain genomic DNA of three fungal strains, the mycelia were macerated with a mortar and pestle in TES lysis buffer (Tris $100 \mathrm{mM}$; EDTA $10 \mathrm{mM}$; 2\% SDS). First, lysed tissue was incubated at $65^{\circ} \mathrm{C}$ for $15 \mathrm{~min}$. Then, $140 \mu \mathrm{L}$ of $5 \mathrm{M} \mathrm{NaCl}$ were added, and the mixture was incubated on ice for $30 \mathrm{~min}$. Afterward, $600 \mu \mathrm{L}$ of chloroform/isoamyl alcohol (24:1) were added and centrifuged at $10,000 \times g$ for $10 \mathrm{~min}$ at $4{ }^{\circ} \mathrm{C}$. The supernatant was isolated and mixed with $50 \mu \mathrm{L}$ sodium acetate $3 \mathrm{M}(\mathrm{pH}$ 5.2) and $300 \mu \mathrm{L}$ isopropanol. After the second centrifugation under the same conditions, the supernatant was discarded, and the mixture was washed twice with $600 \mu \mathrm{L}$ of $70 \%$ ethanol following centrifugation steps. After discarding the final supernatant, the resulting pellet was diluted in $50 \mu \mathrm{L}$ TE buffer (Tris $10 \mathrm{mM}$; EDTA $1 \mathrm{mM}$ ) and $5 \mu \mathrm{L}$ RNAse $(10 \mathrm{mg} / \mathrm{mL})$. 


\subsubsection{Polymerase Chain Reaction}

Genomic DNA was used to amplify the fungal ITS region (ITS1-5.8S-ITS2) applying the primer pairs ITS4 and ITS5 [29]. For amplification reactions, a PCR Master Mix Kit was used (Promega, Madison, WI, USA), following the manufacturer's instructions. To visualize the amplification, product electrophoresis was performed on a $1 \%$ agarose gel stained with Nancy dye (Sigma-Aldrich, Saint Louis, MO, USA). Next, the amplification products were purified using the Wizard ${ }^{\circledR}$ SV Gel kit and PCR Clean-Up System (Promega) following the kit's instructions. Finally, the PCR product was quantified on a NanoDrop ${ }^{\circledR}$ (Thermo Scientific, Waltham, MA, USA).

\subsubsection{DNA Sequencing}

Sequencing reactions were performed with the BigDye ${ }^{\circledR}$ Terminator Cycle Sequencing Kit (Life Technologies, Carlsbad, CA, USA) following the manufacturer's instructions and analyzed with ABI 3500 XL sequencer system (Life Technologies). Resulting forward and reverse sequences were quality checked and merged into a consensus sequence with BioEdit v.7.0.5.3 [30]. The BLASTn tool of the public NCBI-GenBank (www.ncbi.nlm.nih. gov) and the Trichokey database (http://isth.info/) were used to compare contigs with homologous sequences (both accessed on 12 April 2019). After a second, quality control sequences were aligned with homologous sequences from culture collections applying the ClustalW tool [31]. Then, the sequences were subjected to phylogenetic analysis. The phylogeny was assembled using the neighbor-joining method, calculating the evolutionary distance using the 2-parameter Kimura model, and are expressed as the units of the number of base substitutions per site. The rate variation among sites was modeled with a gamma distribution (shape parameter $=1$ ). The analysis involved 58 nucleotide sequences. All positions containing gaps and missing data were eliminated. There was a total of 430 positions in the final data set. Tree support was calculated with bootstrap analysis with 1000 pseudo-replications, and the tree was inferred using MEGA v.7.0 [32].

\subsection{Preparation of Crude Enzyme Extract}

Isolated fungi were pre-cultured at $20^{\circ} \mathrm{C}$ on inclined agar PDA medium in test tubes until sporulation. Concentrations of $10^{6}-10^{7}$ spores per $\mathrm{mL}$ were established in sterile water using a Neubauer chamber for counting. These spores were then used to inoculate $50 \mathrm{~mL}$ of sterile Adam's medium $(\mathrm{pH}=6)$ with $1 \%$ wheat bran in $125 \mathrm{~mL}$ Erlenmeyer flasks (Adam's medium for $50 \mathrm{~mL}: 0.05 \mathrm{~g} \mathrm{KH}_{2} \mathrm{PO}_{4}, 0.025 \mathrm{~g} \mathrm{MgSO} \cdot 7 \mathrm{H}_{2} \mathrm{O}, 0.1 \mathrm{~g}$ yeast extract, and $1 \mathrm{~g}$ glucose $+50 \mathrm{~mL} \mathrm{H} \mathrm{H}_{2} \mathrm{O}$ distilled). Triplicates were incubated at $20{ }^{\circ} \mathrm{C}$ under static and shaking conditions (120 rpm), respectively, for $120 \mathrm{~h}$ harvesting each $24 \mathrm{~h}$. Each crude extract sample from flasks was filtered over Whatman paper using a vacuum pump and applied on the same day for enzyme assays.

\subsection{Enzyme Activity Assay}

\subsubsection{Enzyme Determination with Natural Substrates}

To measure enzyme activity, the crude enzyme extract was mixed with respective water-diluted substrates to obtain activity over time according to the Miller method [33]. Reducing sugars were quantified using 3,5-dinitrosalicylic acid (DNS) combined with 0.5\% carboxymethylcellulose (CMC) (endoglucanase measurement) (Sigma-Aldrich ${ }^{\circledR}$ ) and 0.5\% xylan beechwood (endoxylanase measurement) in the following relation: $25 \mu \mathrm{L}$ substrate,

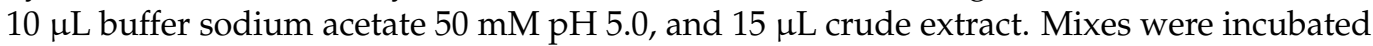
in a thermocycler (Eppendorf ${ }^{\circledR}$, Hamburg, Germany) for $20 \mathrm{~min}$ at $30^{\circ} \mathrm{C}$. In the assay to determine optimal incubation temperatures, a range was established from 4 to $32^{\circ} \mathrm{C}$. Then, $50 \mu \mathrm{L}$ DNS was added to interrupt enzyme activity, and sample-absorbance was measured at $540 \mathrm{~nm}$ on a spectrophotometer (Shimadzu, Kyoto, Japan) compared to glucose and xylose standard curves $(0-1 \mathrm{mg} / \mathrm{mL})$. Blancs were established adding enzyme extract after incubation, directly interrupting the reaction with DNS. The results were expressed as 
milliunits per $\mathrm{mL}(\mathrm{mU} / \mathrm{mL})$, defined as the enzyme quantity that releases one $\mu \mathrm{mol}$ of reducing sugars per minute per $\mathrm{mL}$.

\subsubsection{Enzyme Determination with Synthetic Substrates}

To measure enzyme activity, the crude enzyme extract was mixed with respective water-diluted substrates to obtain activity over time. The amount of released $p$-nitrophenol as a result of enzyme cleavage was measured for the following substrates: $p$-nitrophenol- $\beta$ D-glycopyranoside ( $\beta$-D-glucosidase measurement), $p$-nitrophenol- $\beta$-D-xylanopyranoside ( $\beta$-D-xylosidase measurement), and $p$-nitrophenol- $\beta$-D-cellobiose (exoglucanase measurement) (all substrates obtained from Sigma-Aldrich ${ }^{\circledR}$ ) used in the following relation: $25 \mu \mathrm{L}$ substrate, $10 \mu \mathrm{L}$ sodium acetate buffer $50 \mathrm{mM} \mathrm{pH}$ 5.0, and $15 \mu \mathrm{L}$ crude extract [34].

For the measurement of phosphatases with $p$-nitrophenyl phosphate (acid and alkaline phosphatase), the assay mix was prepared accordingly using $10 \mu \mathrm{L}$ crude extract, $40 \mu \mathrm{L}$ substrate, and $100 \mu \mathrm{L}$ buffer, where acid phosphatase was measured with acetate buffer $100 \mathrm{mM}, \mathrm{pH} 4.5$ and alkaline phosphatase with Tris- $\mathrm{HCl} 100 \mathrm{mM}, \mathrm{pH} 8.0$ (modified according to [35]). Mixes were incubated in a thermocycler (Eppendorf ${ }^{\circledR}$ ) for 20 min at $30^{\circ} \mathrm{C}$. In the assay to determine optimal incubation temperatures, a range was established from 4 to $32{ }^{\circ} \mathrm{C}$ in steps of $4{ }^{\circ} \mathrm{C}$. Then, $50 \mu \mathrm{L}\left(100 \mu \mathrm{L}\right.$ for phosphatases) of $0.2 \mathrm{M} \mathrm{Na}_{2} \mathrm{CO}_{3}$ solution was added to interrupt enzyme activity and sample-absorbance was measured at $410 \mathrm{~nm}$ compared to a $p$-nitrophenol-standard curve $(0-1 \mathrm{mg} / \mathrm{mL})$ [36]. Blancs were established by adding enzyme extract after incubation, directly interrupting the reaction with $\mathrm{Na}_{2} \mathrm{CO}_{3}$ solution. The results are expressed as milliunits per $\mathrm{mL}(\mathrm{mU} / \mathrm{mL})$, defined as the enzyme quantity that releases one $\mu \mathrm{mol}$ of $p$-nitrophenol per minute per $\mathrm{mL}$.

\subsection{Statistical Analysis}

Measured enzyme activity is expressed as the mean \pm standard deviation using Microsoft EXCEL. The Shapiro-Wilk test was used to prove the normal distribution of data and the Levene's test for homoscedasticity. To test for statistical difference between incubation types (i.e., agitation and static), averages of the maximum enzyme activities were compared using the $t$-test for independent variables or Mann-Whitney $U$ test, respectively. To analyze maximum yields among the three studied fungi, one-way ANOVA or KruskalWallis's test were applied following Sidak-Bonferroni or Dunn post-hoc tests. All statistical analyses were performed using licensed STATA 16.0.

\section{Results and Discussion}

\subsection{Sample Site Conditions and Soil Characteristics}

This sampling sites in the Iliniza National Reserve were chosen due to the fact of their proximity to glacial areas of stratified volcanos in the High Andean region. At a $4000 \mathrm{~m}$ altitude, the vegetation zone of conserved paramo highlands is grassland, mainly characterized by herbaceous plants such as sphagnum mosses, tussock grass, and rosette plants (Figure $1 \mathrm{~b}, \mathrm{c}$ ). At $4150 \mathrm{~m}$ asl, the zone of the superparamo builds the frontier between the last zone of abundant vegetation and the beginning of the rocky glacial zone with only sporadic vegetation. Close to the equator, the radiation at this altitude is very high, causing drastic daily temperature changes between day and nighttime with an average temperature of $9.6^{\circ} \mathrm{C}$ (Table S1). Due to the volcanic ash deposition and slow decomposition, the slightly acidic soil ( $\mathrm{pH}$ 5.87-6.15) has mainly a sandy-loam texture with $7.7-9 \%$ organic matter, which is very high, as expected for Andisols [37]. The stabilization of large organic particles also accounts for its vast water retention capacity [38], which, together with the related oxygen availability, directly interferes with the development of microorganisms and the solubilization of phosphorus [39]. The formation of humic acids in the breakdown of organic matter allows for the formation of metal-humus complexes retaining chelated ions like calcium [40] and magnesium [41], which might explain their abundance in analyzed soils and further account for the observed high levels of conductivity [42]. On the other hand, under the environmental conditions of the paramo region, organic matter breakdown is 
slow. It might negatively interfere with nutrient availability due to the microbial activity as indicated by the observed low phosphorus, sulfur [43], and nitrogen levels (Table 1) [44-46].

Table 1. Soil characteristics at sampling sites.

\begin{tabular}{|c|c|c|c|c|c|c|c|c|c|c|c|}
\hline $\begin{array}{c}\text { Sample } \\
\text { Site }\end{array}$ & $\begin{array}{c}\text { Soil } \\
\text { Type }\end{array}$ & Soil Texture & $\mathrm{pH}$ & $\begin{array}{l}\mathrm{COND} \\
\left(\mu \mathrm{S} / \mathrm{cm}^{2}\right)\end{array}$ & $\mathrm{Nt} \%$ & OM \% & $\begin{array}{c}P \\
(\mathrm{ppm})\end{array}$ & $\underset{(\mathrm{ppm})}{\mathrm{S}}$ & $\mathrm{K}$ (meq/100 g) & Ca (meq/100 g) & $\mathrm{Mg}$ (meq/100 g) \\
\hline $\begin{array}{l}1 \\
2\end{array}$ & Andisol & $\begin{array}{l}\text { sandy loam, } \\
\text { loamy }\end{array}$ & $\begin{array}{l}6.15 \\
6.78\end{array}$ & $\begin{array}{l}21.5 \\
21.3\end{array}$ & $\begin{array}{l}0.31 \\
0.36\end{array}$ & $\begin{array}{l}8.8 \\
9.7\end{array}$ & $\begin{array}{c}9.01 \\
14\end{array}$ & $\begin{array}{l}8.4 \\
9.3\end{array}$ & $\begin{array}{l}0.54 \\
0.48\end{array}$ & $\begin{array}{l}9.78 \\
9.76\end{array}$ & $\begin{array}{l}1.71 \\
1.28\end{array}$ \\
\hline $\begin{array}{l}3 \\
4\end{array}$ & Andisol & sandy loam & $\begin{array}{l}5.93 \\
5.87\end{array}$ & $\begin{array}{c}15.51 \\
20.8\end{array}$ & $\begin{array}{l}0.25 \\
0.27\end{array}$ & $\begin{array}{c}7.7 \\
9\end{array}$ & $\begin{array}{c}6.04 \\
12\end{array}$ & $\begin{array}{l}4.7 \\
4.1\end{array}$ & $\begin{array}{l}0.42 \\
0.37\end{array}$ & $\begin{array}{l}7.49 \\
4.87\end{array}$ & $\begin{array}{l}1.01 \\
0.73\end{array}$ \\
\hline
\end{tabular}

$\mathrm{COND}=$ conductivity, $\mathrm{Nt}=$ total nitrogen, and $\mathrm{OM}=$ organic matter.

\subsection{Screening for Cultivable Fungi}

The first screening for cultivable fungal strains from soil samples showed relatively few growing colonies clearly separated from each other, allowing for easy isolation of distinct strains. Out of 12 soil samples, eight colonies were chosen for the study. These strains were further screened for their capacity to grow at different temperature conditions. Generally, all strains showed better growth at $4{ }^{\circ} \mathrm{C}$ than $30^{\circ} \mathrm{C}$, indicating their adaptation to cold environments (Figure S1). At $40^{\circ} \mathrm{C}$, no development could be detected. The results showed a potentially psychrophilic profile for the best growing behavior of strain 3.3 at $4{ }^{\circ} \mathrm{C}$ given that it was not able to grow at $30^{\circ} \mathrm{C}$ and psychrotrophic profiles for the strains 1.1 and 3.1 at $30^{\circ} \mathrm{C}[5]$, which were chosen for further experimentation (Figure S2).

\subsection{Identification of Fungi}

Phylogenetic analysis of the ITS region revealed that all three fungi were ascomycetes with strains 1.1 and 3.1 belonging to the genus Cladosporium: C. michoacanense and Cladosporium sp. 3.1 (C. Cladosporioides species complex), respectively, and 3.3 to the genus Didymella (Figure 2). Since the ITS region is not sufficient for species delimitation in some of these groups, other secondary barcodes would be needed for more accurate identification. The genus Cladosporium is a highly heterogeneous group with cosmopolitan distribution and strong capability of adaptation [47] with species formerly isolated from arctic soils [8,23] and marine sponges [48]. A third strain belonged to the genus Didymella which has mainly been studied due to the existence of pathological strains and plant-host interaction [49] but so far to a lesser extent due to the fact of its resistance to extreme conditions and, therefore, its arising enzymatic capacities [50]. Both Cladosporium and Didymella strains have formerly been reported in soil isolates from Himalaya mountain environments [51,52]. Still, only Cladosporium has formerly been described for Andean regions [12,14], and the present study is the first registry of the genus Didymella in the paramo ecosystem.

Images taken of the growth behavior in culture dishes of PDA indicate a dark brown colorization of mycelia, which possibly shows intense melanin pigmentation as a protective adaptation to the strong radiation in their natural habitat as formerly described [53,54] (Figure S3d-f). Furthermore, differential growth behavior was detected under static and agitation conditions (Figure S3g-i). Especially, the Cladosporium strains tended to grow better under agitation, developing a darker aspect apparently due to the stronger sporulation [55]. Meanwhile, its impact on Didymella was less evident. 


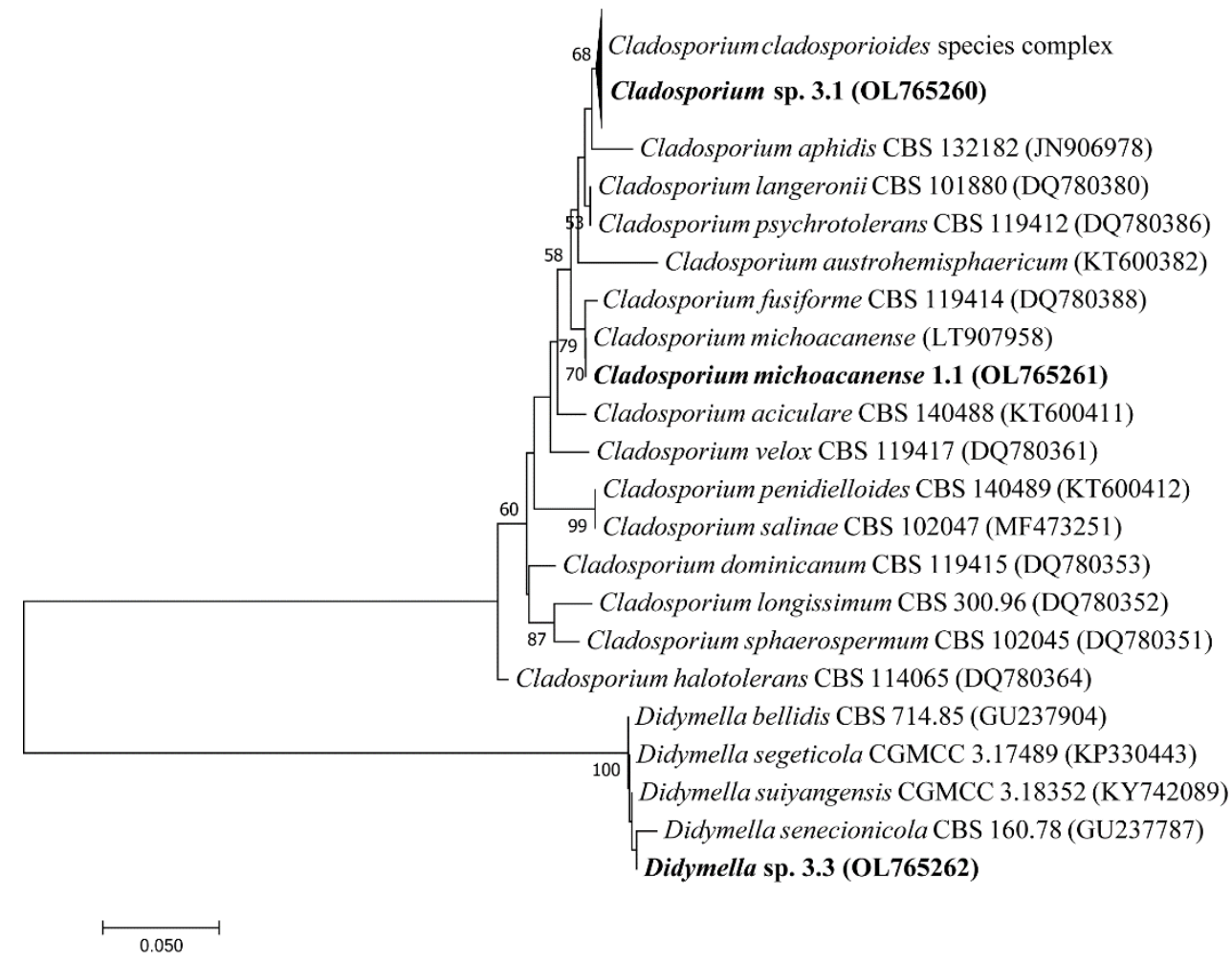

Figure 2. Phylogenetic analysis of filamentous fungi isolated from paramo soil samples (bold) and the closest related species.

\subsection{Enzymatic Characterization}

The following section shows the incubation time-dependent enzyme secretion results from 24 to $120 \mathrm{~h}$ under agitation and static condition for each isolated fungal strain to characterize the hydrolyzation capacities at $30^{\circ} \mathrm{C}$.

\subsubsection{Enzymatic Production of Cladosporium michoacanense}

Cladosporium michoacanense 1.1 showed the most potent activation under agitation with a relatively late onset of enzyme secretion compared to studies analyzing the same enzymes [34] (Table 2). The most significant activity was detected at $72 \mathrm{~h}$ for the hydrolyzation of CMC, xylan, and pnp-phosphate in an alkaline medium; $96 \mathrm{~h}$ for $p$ np- $\beta$ D-glycopyranoside; $120 \mathrm{~h}$ for $p$ np- $\beta$-D-cellobiose, $p$ np- $\beta$-D-xylanopyranoside, and $p n p$ phosphate in acidic medium, indicating statistically significant differences to measurements under static conditions for all enzymes except for exoglucanase and $\beta$-glucosidase. Interestingly, under static incubation conditions, the most potent enzyme activity was measured early between 24 to $48 \mathrm{~h}$ for endoglucanase, xylanase, $\beta$-xylosidase, and alkaline phosphatase and late response at $120 \mathrm{~h}$ for exoglucanase, $\beta$-glucosidase, and acid phosphatase. Overall, the most efficient enzyme activity for endoglucanase and xylanase could be observed at levels well above $2000 \mathrm{mU} / \mathrm{mL}$ under agitated cultivation. 
Table 2. Cladosporium michoacanense 1.1 enzymes produced overtime under agitation and static conditions.

\begin{tabular}{|c|c|c|c|c|c|c|c|c|c|c|}
\hline \multirow[b]{2}{*}{ Enzyme } & \multicolumn{5}{|c|}{ Agitation } & \multicolumn{5}{|c|}{ Static } \\
\hline & $24 \mathrm{~h}$ & $48 \mathrm{~h}$ & $72 \mathrm{~h}$ & $96 \mathrm{~h}$ & $120 \mathrm{~h}$ & $24 \mathrm{~h}$ & $48 \mathrm{~h}$ & $72 \mathrm{~h}$ & $96 \mathrm{~h}$ & $120 \mathrm{~h}$ \\
\hline Endoglucanase & $\begin{array}{c}932.2 \pm \\
20.7\end{array}$ & $\begin{array}{c}1514.4 \pm \\
100.5\end{array}$ & $\begin{array}{r}2503.7 \pm \\
207.1^{*}\end{array}$ & $\begin{array}{c}394.5 \pm \\
51.8\end{array}$ & $\begin{array}{c}385.2 \pm \\
170.0\end{array}$ & $\begin{array}{l}887.4 \pm \\
84.8\end{array}$ & $\begin{array}{c}1061.0 \pm \\
23.3\end{array}$ & $\begin{array}{c}917.6 \pm \\
17.1\end{array}$ & $\begin{array}{l}791.4 \pm \\
70.4\end{array}$ & $\begin{array}{c}730.6 \pm \\
26.9\end{array}$ \\
\hline Exoglucanase & ND & ND & ND & $1.4 \pm 0.7$ & $1.4 \pm 0.3$ & ND & ND & ND & ND & $0.2 \pm 0.1$ \\
\hline $\begin{array}{c}\beta- \\
\text { Glucosidase } \\
\end{array}$ & ND & ND & ND & $1.7 \pm 0.0$ & ND & ND & ND & ND & ND & $0.2 \pm 0.0$ \\
\hline Xylanase & $\begin{array}{c}360.2 \pm \\
105.7 \\
\end{array}$ & $\begin{array}{c}969.4 \pm \\
120.1 \\
\end{array}$ & $\begin{array}{c}2430.1 \pm \\
2.1\end{array}$ & $\begin{array}{c}274.6 \pm \\
81.3 \\
\end{array}$ & $\begin{array}{c}145.2 \pm \\
34.7 \\
\end{array}$ & $\begin{array}{c}737.8 \pm \\
88.3\end{array}$ & $\begin{array}{c}435.5 \pm \\
111.7 \\
\end{array}$ & $\begin{array}{c}412.2 \pm \\
53.9\end{array}$ & $\begin{array}{c}353.0 \pm \\
119.5 \\
\end{array}$ & $\begin{array}{c}384.3 \pm \\
70.6\end{array}$ \\
\hline$\beta$-Xylosidase & ND & ND & $0.7 \pm 0$ & $1.1 \pm 0.3$ & $1.4 \pm 0.3 *$ & $0.5 \pm 0.1$ & ND & ND & ND & ND \\
\hline $\begin{array}{c}\text { Acid } \\
\text { phosphatase }\end{array}$ & $1.4 \pm 0.6$ & $1.7 \pm 1.0$ & $31.0 \pm 0.3$ & 5.9 & $34.9 \pm 0.1 *$ & ND & ND & ND & ND & $0.7 \pm 0.4$ \\
\hline $\begin{array}{c}\text { Alkaline } \\
\text { phosphatase }\end{array}$ & $0.3 \pm 0.1$ & $1.4 \pm 0.3$ & $2.3 \pm 0.4$ * & $0.2 \pm 0.2$ & ND & $1.4 \pm 0.3$ & $0.6 \pm 0.3$ & ND & ND & ND \\
\hline
\end{tabular}

Data are expressed as $\mathrm{mU} / \mathrm{mL} \pm$ standard deviation. $\mathrm{ND}=$ not detected; ${ }^{*}$ indicates a statistically significant difference $(p<0.05)$ between the average enzyme activity of fungi cultivated under agitation vs. static conditions for each analyzed enzyme. In bold, maximum achieved activity.

\subsubsection{Enzymatic Production of cladosporium sp. (C. Cladosporioides Species Complex)}

Cladosporium sp. 3.1 indicated the best hydrolyzation performance under agitation at $120 \mathrm{~h}$ for most enzymes (Table 3). The late onset in enzyme production is consistent with previous studies [56]. Exceptions were endoglucanase with the highest enzyme secretion at $48 \mathrm{~h}, \beta$-xylosidase at $24 \mathrm{~h}$, and xylanase at $72 \mathrm{~h}$. Under static conditions, the strongest enzyme secretion was observed at 72-96 h for most enzymes with significantly lower activity values than under agitation conditions, which is coherent with the increased pellet formation observed by comparing the incubation flasks of $C$. Cladosporioides under static and agitation conditions (Figure S3g,h). This phenomenon was formerly described by Raikumar et al. for this genus [55]. Xylanase was the only exception that performed better under static conditions at $72 \mathrm{~h}$ of incubation. Agitation leads to better aeration and distribution of heat and nutrients bearing growth benefits for many filamentous fungi [57]. Comparing both analyzed Cladosporium species, an advanced enzyme production upon agitation was observed, and a relative early specialization in the production of endoglucanase and xylanase indicated a focus on the breakdown of large sugar polymers such as cellulose and hemicellulose [58]. All remaining enzymes showed a rather late onset.

Table 3. Cladosporium cladosporioides sp. 3.1 enzyme activity over time und agitation and static conditions.

\begin{tabular}{|c|c|c|c|c|c|c|c|c|c|c|}
\hline \multirow[b]{2}{*}{ Enzyme } & \multicolumn{5}{|c|}{ Agitation } & \multicolumn{5}{|c|}{ Static } \\
\hline & $24 \mathrm{~h}$ & $48 \mathrm{~h}$ & $72 \mathrm{~h}$ & $96 \mathrm{~h}$ & $120 \mathrm{~h}$ & $24 \mathrm{~h}$ & $48 \mathrm{~h}$ & $72 \mathrm{~h}$ & $96 \mathrm{~h}$ & $120 \mathrm{~h}$ \\
\hline Endoglucanase & $\begin{array}{c}393.2 \pm \\
97.3\end{array}$ & $\begin{array}{c}1274.0 \pm \\
102.0\end{array}$ & $\begin{array}{c}328.5 \pm \\
68.6\end{array}$ & $14.0 \pm 11.4$ & $14.6 \pm 11.9$ & $\begin{array}{c}761.0 \pm \\
70.4\end{array}$ & $\begin{array}{c}638.8 \pm \\
140.4\end{array}$ & $\begin{array}{c}945.3 \pm \\
120.6\end{array}$ & $\begin{array}{c}1076.4 \pm \\
149.4\end{array}$ & $\begin{array}{c}775.0 \pm \\
156.2\end{array}$ \\
\hline Exoglucanase & ND & ND & $3.6 \pm 1.0$ & $6.0 \pm 0.3$ & $12.0 \pm 0.6^{*}$ & ND & ND & $0.7 \pm 0.4$ & $0.9 \pm 0.6$ & $1.0 \pm 0.0$ \\
\hline $\begin{array}{c}\beta- \\
\text { Glucosidase } \\
\end{array}$ & $0.2 \pm 0.2$ & $0.8 \pm 0.2$ & $5.7 \pm 1.0$ & $8.7 \pm 2.9$ & $11.1 \pm 0.8^{*}$ & ND & ND & $0.7 \pm 0.4$ & ND & ND \\
\hline Xylanase & $156.0 \pm 8.3$ & $\begin{array}{c}861.0 \pm \\
11.9\end{array}$ & $\begin{array}{c}958.9 \pm \\
15.5\end{array}$ & $\begin{array}{c}481.0 \pm \\
57.0\end{array}$ & ND & $\begin{array}{l}522.1 \pm \\
87.6\end{array}$ & $\begin{array}{c}660.0 \pm \\
56.1\end{array}$ & $\begin{array}{c}1113.0 \\
865\end{array}$ & $\begin{array}{c}937.3 \pm \\
40.4\end{array}$ & $\begin{array}{c}898.0 \pm \\
62.1\end{array}$ \\
\hline$\beta$-Xylosidase & $1.2 \pm 0.3$ & $0.4 \pm 0.1$ & ND & ND & ND & $1.0 \pm 0.1$ & ND & ND & ND & ND \\
\hline $\begin{array}{c}\text { Acid } \\
\text { phosphatase }\end{array}$ & $0.7 \pm 0.4$ & $1.9 \pm 0.7$ & $3.4 \pm 0.7$ & $6.8 \pm 0.3$ & $13.9 \pm 0.5 *$ & ND & ND & $0.3 \pm 0.2$ & $1.0 \pm 0.7$ & $0.9 \pm 0.1$ \\
\hline $\begin{array}{c}\text { Alkaline } \\
\text { phosphatase }\end{array}$ & $\mathrm{ND}$ & ND & $1.2 \pm 0.8$ & $1.9 \pm 1.6$ & $8.0 \pm 1.5 *$ & ND & ND & ND & ND & $1.0 \pm 0.3$ \\
\hline
\end{tabular}

Data are expressed as $\mathrm{mU} / \mathrm{mL} \pm$ standard deviation. $\mathrm{ND}=$ not detected; ${ }^{*}$ indicates a statistically significant difference $(p<0.05)$ between the average enzyme activity of fungi cultivated under agitation vs. static conditions for each analyzed enzyme. In bold, maximum achieved activity.

\subsubsection{Enzymatic Production of Didymella sp.}

The Didymella strain 3.3 showed a rather heterogeneous behavior (Table 4). Meanwhile, $\mathrm{CMC}$ and $p$ np- $\beta$-D-xylanopyranoside were most effectively hydrolyzed under agitation at $24 \mathrm{~h}$ and $48 \mathrm{~h}$, respectively. However, the best xylan hydrolyzation occurred at $72 \mathrm{~h}$ and for $p$ np- $\beta$-D-glycopyranoside, $p$ np- $\beta$-D-cellobiose, and $p$ np-phosphate in alkaline medium at 
$96 \mathrm{~h}$ and $120 \mathrm{~h}$ in acid medium. Interestingly, while $\beta$-glucosidase, $\beta$-xylosidase, acid, and alkaline phosphatase showed low but detectable activity under agitation conditions, no activity could be detected under static conditions. On the other hand, endoglucanase, and xylanase, which generally showed much higher activity, performed considerably stronger under static conditions at $96 \mathrm{~h}$. These results confirm the previously described strong influence that culture conditions can exert over enzyme production [34,59].

Table 4. Didymella sp. strain 3.3 enzyme activity over time und agitation and static conditions.

\begin{tabular}{|c|c|c|c|c|c|c|c|c|c|c|}
\hline & & & Agitation & & & & & Static & & \\
\hline Enzyme & $24 \mathrm{~h}$ & $48 \mathrm{~h}$ & $72 \mathrm{~h}$ & $96 \mathrm{~h}$ & $120 \mathrm{~h}$ & $24 \mathrm{~h}$ & $48 \mathrm{~h}$ & $72 \mathrm{~h}$ & $96 \mathrm{~h}$ & $120 \mathrm{~h}$ \\
\hline Endoglucanase & $\begin{array}{c}1077.4 \pm \\
6.7\end{array}$ & $\begin{array}{c}1037.4 \pm \\
99.0\end{array}$ & $354.5 \pm 6.7$ & $\begin{array}{c}334.4 \pm \\
10.9\end{array}$ & $\begin{array}{c}119.0 \pm \\
39.4\end{array}$ & $\begin{array}{c}870.1 \pm \\
99.8\end{array}$ & $\begin{array}{c}1243.0 \pm \\
108.1\end{array}$ & $\begin{array}{c}1151.6 \pm \\
189.5\end{array}$ & $\begin{array}{r}1413.0 \pm \\
165.7^{*}\end{array}$ & $\begin{array}{c}926.7 \pm \\
15.0\end{array}$ \\
\hline Exoglucanase & $0.4 \pm 0.2$ & $0.7 \pm 0.2$ & $1.0 \pm 0.3$ & $1.7 \pm 0.4$ & $1.7 \pm 0.4$ & $0.7 \pm 0.2$ & $1.7 \pm 0.1$ & $0.6 \pm 0.2$ & ND & ND \\
\hline $\begin{array}{c}\beta- \\
\text { Glucosidase } \\
\end{array}$ & ND & ND & ND & $1.6 \pm 0.7$ & $0.5 \pm 0.1$ & ND & ND & ND & ND & ND \\
\hline Xylanase & $\begin{array}{c}202.3 \pm \\
15.0\end{array}$ & $\begin{array}{l}233.0 \pm \\
98.2\end{array}$ & $\begin{array}{c}383.0 \pm \\
103.2\end{array}$ & $\begin{array}{c}289.2 \pm \\
62.1\end{array}$ & ND & $\begin{array}{c}873.2 \pm \\
93.7\end{array}$ & $\begin{array}{c}893.3 \pm \\
125.9 \\
\end{array}$ & $\begin{array}{c}906.0 \pm \\
186.4 \\
\end{array}$ & $\begin{array}{c}1623.5 \pm \\
196.4^{*}\end{array}$ & $\begin{array}{c}624.7 \pm \\
141.4 \\
\end{array}$ \\
\hline$\beta$-Xylosidase & $1.0 \pm 0.0$ & $0.5 \pm 0.1$ & $0.4 \pm 0.1$ & $0.1 \pm 0.0$ & ND & ND & ND & ND & ND & ND \\
\hline $\begin{array}{c}\text { Acid } \\
\text { phosphatase }\end{array}$ & ND & $2.7 \pm 0.6$ & $5.7 \pm 1.1$ & $7.3 \pm 1.1$ & $7.5 \pm 1.5$ & ND & ND & ND & ND & $0.3 \pm 0.1$ \\
\hline $\begin{array}{c}\text { Alkaline } \\
\text { phosphatase }\end{array}$ & $0.4 \pm 0.3$ & $0.4 \pm 0.1$ & $1.8 \pm 0.1$ & $2.1 \pm 0.5$ & ND & ND & ND & ND & ND & ND \\
\hline
\end{tabular}

Data are expressed as $\mathrm{mU} / \mathrm{mL} \pm$ standard deviation. $\mathrm{ND}=$ not detected; ${ }^{*}$ indicates a statistically significant difference $(p<0.05)$ between the average enzyme activity of fungi cultivated under agitation vs. static conditions for each analyzed enzyme. In bold, maximum achieved activity.

\subsubsection{Comparison of Relative Enzyme Activity between Acid and Alkaline Phosphatases}

Analysis of differential enzyme production between acid and alkaline phosphatase activities generally indicated more substantial secretion of enzymes upon agitation than under static conditions and stronger and prolonged acid phosphatase activity over time. Meanwhile, alkaline phosphatase showed lower and somewhat restricted activation at growth onset for strains 1.1 and 3.1; activation was strongest from 72 to $120 \mathrm{~h}$ for strain 3.1 (Figure S4). This behavior matches with the environmental conditions of their habitat, where slightly acidic soil pH was observed (Table 2), which is also the preferred growth condition for most fungi [60]. It further coincides with the tendency that within strain 1.1 and 3.1, measured $\mathrm{pH}$ values of crude extract used to drop stronger over time than in strain 3.3 (Figure S5).

\subsubsection{Temperature-Dependent Enzyme Activity}

After analyzing the best growth time for differential enzyme production, results were used to determine optimal enzyme secretion under different incubation temperatures ranging from 4 to $32{ }^{\circ} \mathrm{C}$ under agitation to optimize enzyme production further. The results indicated statistically significant differences among strains (Figure 3). Meanwhile, strain 1.1 showed the best performance at temperatures ranging from 20 to $24{ }^{\circ} \mathrm{C}$ for all enzymes related to the carbon cycle and $8-12{ }^{\circ} \mathrm{C}$ for phosphatases; strain 3.1 showed somewhat differential activity indicating main enzyme activity for $\beta$-glucosidase and exoglucanase from 4 to $8^{\circ} \mathrm{C}$ and for endoglucanase, $\beta$-xylosidase, and xylanase from 20 to $24^{\circ} \mathrm{C}$. Phosphatases showed opposite behavior with the highest acid phosphatase activity at $12{ }^{\circ} \mathrm{C}$; meanwhile, alkaline phosphatase performed best at $28{ }^{\circ} \mathrm{C}$. This controversial behavior might best be explained by the adaptation capacity of different Cladosporium species to varying ecological niches giving rise to its worldwide abundance [47]. It is typical for fungal strains adapted to changing environmental conditions within a single habitat [61,62]. Strain 3.3 finally showed maximum activity for $\beta$-glucosidase, endoglucanase, and xylanase at $8{ }^{\circ} \mathrm{C}$ and for exoglucanase and $\beta$-xylosidase at $20-24^{\circ} \mathrm{C}$. Phosphatase activity remained low, with the highest activity at $16^{\circ} \mathrm{C}$ for both acid and alkaline phosphatase. 


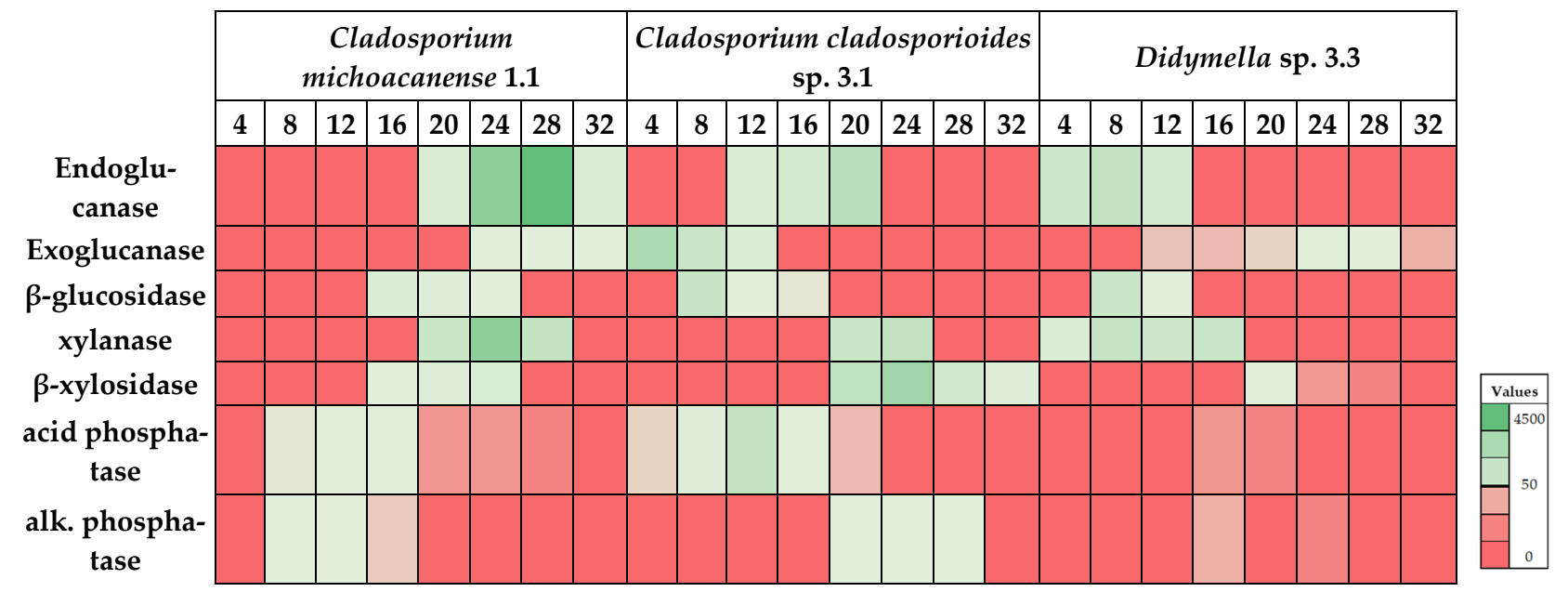

Figure 3. Heatmap analysis of incubation temperature $\left({ }^{\circ} \mathrm{C}\right)$ dependent enzyme performance for each isolated strain. Maximum values $\pm \mathrm{SD}$ (in $\mathrm{mU} / \mathrm{mL}$ ) are summarized in Table 5 .

Table 5. Maximum enzyme activity yield at optimal assay temperature and incubation time for each isolated strain.

\begin{tabular}{|c|c|c|c|c|c|c|c|c|c|}
\hline \multirow[b]{2}{*}{ Enzyme } & \multicolumn{3}{|c|}{ Cladosporium michoacanense 1.1} & \multicolumn{3}{|c|}{ Cladosporium Cladosporioides Complex 3.1} & \multicolumn{3}{|c|}{ Didymella sp. 3.3} \\
\hline & $\underset{\text { Yield } \pm \text { SD }}{\text { Maximum }}$ & T opt ${ }^{\circ} \mathrm{C}$ & IT (h) & $\underset{\text { Yield } \pm \text { SD }}{\text { Maximum }}$ & T opt ${ }^{\circ} \mathrm{C}$ & IT (h) & $\underset{\text { Yield } \pm \text { SD }}{\text { Maximum }}$ & T opt ${ }^{\circ} \mathrm{C}$ & IT (h) \\
\hline Endoglucanase & $4563 \pm 209^{a}$ & 28 & 72 & $1553 \pm 330^{b}$ & 20 & 48 & $1247 \pm 21^{b}$ & 8 & 72 \\
\hline Exoglucanase & $107 \pm 26^{\mathrm{a}}$ & 24 & 96 & $2037 \pm 254^{b}$ & 4 & 120 & $127 \pm 5^{\mathrm{a}}$ & 24 & 96 \\
\hline$\beta$-Glucosidase & $303 \pm 39^{a}$ & 16 & 96 & $1013 \pm 151^{b}$ & 8 & 96 & \multirow{2}{*}{$\begin{array}{c}917 \pm 12^{b} \\
1150 \pm 121\end{array}$} & 8 & 120 \\
\hline Xylanase & $3036 \pm 634^{\mathrm{a}}$ & 24 & 72 & $1290 \pm 122 \mathrm{ab}$ & 24 & 72 & & 8 & 96 \\
\hline$\beta$-Xylosidase & $430 \pm 29^{a b}$ & 24 & 120 & $2457 \pm 336^{a}$ & 24 & 120 & $71 \pm 5^{b}$ & 20 & 48 \\
\hline $\begin{array}{l}\text { Acid } \\
\text { phosphatase }\end{array}$ & $97 \pm 12^{a b}$ & 12 & 120 & $1273 \pm 360^{\mathrm{a}}$ & 12 & 120 & $17 \pm 5^{b}$ & 16 & 120 \\
\hline $\begin{array}{l}\text { Alkaline } \\
\text { phosphatase }\end{array}$ & $127 \pm 21^{a}$ & 8 & 72 & $137 \pm 37^{b}$ & 28 & 120 & $26 \pm 7^{a}$ & 16 & 96 \\
\hline
\end{tabular}

Data expressed are as $\mathrm{mU} / \mathrm{mL} \pm$ standard deviation. IT = optimal incubation time; $\mathrm{ND}=$ not detected; the letters ${ }^{a}$ and ${ }^{b}$ indicate statistically significant differences among enzyme activities comparing the three different fungi $(p<0.05)$ if the letters are not shared between activities of the same enzyme.

The combination of optimal incubation time, agitation, and optimal substrate incubation temperature led to several enzymes' considerably higher activity (Table 5). Cladosporium strain 1.1 specialized in producing endoglucanase and xylanase with 4.56 and $3.03 \mathrm{U} / \mathrm{mL}$ activities, respectively, both showing significantly higher performances than the other two strains. Comparing these values with formerly described enzymatic activities, even in the mesophilic fungi screenings, especially endoglucanase values, they are quite competitive. For instance, Grujic et al. (2019) [63] described maximum values of $1.1 \mathrm{U} / \mathrm{mL}$ for endoglucanase in Trichoderma guizhouense, Ghazali et al. (2019) [64] reported the highest values of $3.93 \mathrm{U} / \mathrm{mL}$ for Trichoderma asperellum and $5.6 \mathrm{U} / \mathrm{mL}$ for Aspergillus niger. Unfortunately, most studies for psychrotrophic fungi do not apply optimization assays, so comparability is limited. However, considering the advantage of growing under extreme conditions, the Cladosporium michoacanense strain is an interesting candidate for potential industrial application under harsh conditions. Moreover, the relatively early onset of enzyme secretion, indicating efficient substrate hydrolyzation at $72 \mathrm{~h}$, represents an important advantage confirming previous results from studies with Cladosporium strains [58,65].

On the other hand, Cladosporium sp. 3.1 did not reach values as high as strain 1.1 but managed to perform well for all selected enzymes with values above $1 \mathrm{U} / \mathrm{mL}$ except alkaline phosphatase. However, the onset of enzyme production appeared relatively late. Interestingly, strain 3.1 showed the significantly highest activation of $2.04 \mathrm{U} / \mathrm{mL}$ for exoglucanase at low temperatures, although former studies indicated a relatively poor performance of paramo-derived fungi for these enzymes [11]. Comparing the mesophilic 
fungi, results matched with reported highest activities of $1.08 \mathrm{U} / \mathrm{mL}$ and $2.37 \mathrm{U} / \mathrm{mL}$ in Trichoderma asperellum and Aspergillus niger, respectively. It is also important to mention that this high activity was reached under conditions of only $4{ }^{\circ} \mathrm{C}$. Furthermore, $\beta$-glucosidase, which works synergistically with exoglucanase, also performed well at low temperatures $\left(8^{\circ} \mathrm{C}\right)$. Given that Cladosporium cladosporioides had formerly been described to exhibit laccase activity $[58,66,67]$, further studies are needed to determine whether the strain could exhibit lignocellulolytic activity for industrial applications under cold conditions. Moreover, strain 3.1 showed the strongest activation for acid phosphatase, reaching $1.27 \mathrm{U} / \mathrm{mL}$. This result further highlights the importance of applying optimization assays for psychrotolerant enzyme activity given incubation time as well as incubation temperature strongly influenced activity. Therefore, maximum acid phosphatase activity in psychrotrophic fungi of $0.03 \mathrm{U} / \mathrm{mL}$, such as described in a screening study by Gawas-Sakhalkar et al. [68], indicates only a limited comparability to the present results.

Finally, Didymella 3.3 performed well only for endoglucanase, $\beta$-glucosidase, and xylanase, indicating poor performance for the rest of the enzymes, especially phosphatases, which could be related to the phytopathological behavior of many Didymella species allowing for the absorption of nutrients from hosts [49]. Nevertheless, all enzymes that performed better showed the highest values at low temperatures of $8{ }^{\circ} \mathrm{C}$, indicating its potential in producing cold-adapted enzymes [9].

Wide-ranging comparison of psychrotrophic fungi enzyme activity is difficult, given that most screening studies indicate qualitative and semi-quantitative data [7,62,69-71] or activity data at a single temperature and incubation time [61], which is not directly comparable to the presented data. This strongly indicates the importance of performing studies with a more profound analysis of maximum achievable enzyme activities under optimized conditions for psychrotrophic and psychrophilic fungi isolated from habitats with extreme conditions.

\section{Conclusions}

The present study directly isolated cold-adapted fungal strains from high Andean Paramo soil, of which three strains were chosen to identify the genus and characterize their enzymatic capacity. Selecting for optimal conditions concerning growth period, incubation conditions, and optimal temperature for enzyme performance, maximum enzyme activities were determined for each strain. Cladosporium sp. strain 1.1 showed the most competitive enzyme activity of all analyzed strains for endoglucanase and xylanase at $72 \mathrm{~h}$, and agitation and assay temperatures between 24 and $28{ }^{\circ} \mathrm{C}$, indicating an interesting potential for the industrial application processes where reducing sugars are used such as feed animal, food industry, and fuel production. Cladosporium strain 3.1 of the cladosporioides complex indicated average performance for a broad spectrum of different enzymes except for exoglucanase, which showed the highest activity. Its good performance of acid phosphatase at $12{ }^{\circ} \mathrm{C}$ could be applied in the industry of biofertilization to improve the crop yield of plants grown under cold conditions and in the eutrophication of phosphorus from animal feces due to the consumption of phytate in grains [72]. Finally, the Didymella strain 3.3 showed high endoglucanase, $\beta$-glucosidase, and xylanase activities at temperatures as low as $8{ }^{\circ} \mathrm{C}$, where most enzymes are inactivated. This strain responded closest to a psychrotrophic profile, which could be specifically interesting in industrial processes such as wastewater management and bioremediation in cold conditions, an aspect that might become increasingly important in an industrialized world tending towards energy reduction.

Supplementary Materials: The following are available online at https:/ / www.mdpi.com/article/ 10.3390/microorganisms10020282/s1, Figure S1: Growth of 8 different isolated fungal strains; Figure S2. Growth curves of isolated fungal strains at $4{ }^{\circ} \mathrm{C}$ and $30^{\circ} \mathrm{C}$; Supplementary Figure S3: Selected and identified fungi, from left to right Cladosporium michoacanense $(\mathrm{a}, \mathrm{d}, \mathrm{g})$, Cladosporium $\mathrm{sp}$. (cladosporioides species complex)(b, e, h), Didymella sp. (c, f, i); Figure S4: Relative phosphate activity over time comparing acidic phosphatase versus alkaline phosphatase; Figure S5: Development of 
growth medium $\mathrm{pH}$ over time in cultures under agitation (A) and static (S) conditions for strain 1.1, 3.1 and 3.3; Table S1: Sampling sites characteristic.

Author Contributions: Conceptualization, S.A.B., M.d.L.T.d.M.P., and P.G.-T.; methodology, A.G.C., M.C., P.G.-T. and T.B.d.O.; formal analysis, S.A.B. and A.G.C.; resources, M.d.L.T.d.M.P., T.B.d.O. and P.G.-T.; data curation, S.A.B., A.G.C. and T.B.d.O.; writing-original draft preparation, S.A.B.; essay-review and editing, A.G.C., T.B.d.O., M.d.L.T.d.M.P., M.C. and P.G.-T.; visualization, S.A.B.; supervision and funding acquisition, M.d.L.T.d.M.P. All authors have read and agreed to the published version of the manuscript.

Funding: The authors thank the PhD program agreement between the Faculty of Medicine of the Central University of Ecuador and the Faculty of Medicine of the University of São Paulo in Ribeirao Preto which granted a doctorate scholarship to S.A.B. The authors thank Fundação de Amparo à Pesquisa do Estado de São Paulo (FAPESP) for the doctorate grants awarded to A.G.C. (Process no. 2017/25862-6) and the post-doctorate grant awarded to T.B.d.O. (Process no. 2017/09000-4), as well as the financial support from Process no. FAPESP 2008/57908-6 and 2014/50884-5 and Process no. 2018/07522-6, and the Conselho Nacional de Desenvolvimento Científico (CNPq) Process no. 574002/2008-1 and 465319/2014-9. M.L.T.M.P. (Process no. 301963/2017-7) is a Research Fellow at $\mathrm{CNPq}$.

Institutional Review Board Statement: Not applicable.

Informed Consent Statement: Not applicable.

Data Availability Statement: Not applicable.

Acknowledgments: We thank the whole staff at the Laboratory for Applied Microbiology and Biotechnology, especially Emanuelle Neiverth de Freitas, Guilherme Aranha, Rosymar Coutinho de Lucas, and Thiago Pasin for laboratory support; Kevin Toapanta for QGIS support; Wendy Pacheco, Liliana Rojas, Sandy Arguello, and Paola Buitron for fieldwork support in the paramo. Furthermore, we want to thank Rosa Batallas and Diego Inclán at the National Institute of Biodiversity (INABIO) and Carlos Valles at the Ecuadorian Ministry of Environment (MAAE) for the support in permissions to access genetic resources granted in "Contrato Marco No. MAE-DNB-CM-2016-0045".

Conflicts of Interest: The authors declare no conflict of interest. The funders had no role in the study's design, in the collection, analyses, or interpretation of data, in the writing of the manuscript, or in the decision to publish the results.

\section{References}

1. Jiménez-Rivillas, C.; García, J.J.; Quijano-Abril, M.A.; Daza, J.M.; Morrone, J.J. A new biogeographical regionalisation of the Páramo biogeographic province. Aust. Syst. Bot. 2018, 31, 296-310. [CrossRef]

2. Buytaert, W.; Deckers, J.; Wyseure, G. Regional variability of volcanic ash soils in south Ecuador: The relation with parent material, climate and land use. Catena 2007, 70, 143-154. [CrossRef]

3. Bader, M.Y.; van Geloof, I.; Rietkerk, M. High solar radiation hinders tree regeneration above the alpine treeline in northern Ecuador. Plant Ecol. 2007, 191, 33-45. [CrossRef]

4. Paucar, B.; Carpio, M.; Alvarado Ochoa, S.P.; Valverde, F.; Parra, R. Análisis de Solubilizadores de Fósforo en Los Suelos Andisoles de Sierra Norte y Centro de Ecuador. Simposio “El Suelo y la Nutrición de Cultivos en el Ecuador". 2015. Available online: http:/ / repositorio.iniap.gob.ec/handle/41000/2501 (accessed on 9 September 2021).

5. Hassan, N.; Rafiq, M.; Hayat, M.; Shah, A.A.; Hasan, F. Psychrophilic and psychrotrophic fungi: A comprehensive review. Rev. Environ. Sci. Biotechnol. 2016, 15, 147-172. [CrossRef]

6. Rafiq, M.; Hassan, N.; Rehman, M.; Hasan, F. Adaptation mechanisms and applications of psychrophilic fungi. In Fungi in Extreme Environments: Ecological Role and Biotechnological Significance; Tiquia-Arashiro, S.M., Grube, M., Eds.; Springer International Publishing: Cham, Switzerland, 2019; pp. 157-174. [CrossRef]

7. Duarte, A.W.F.; Barato, M.B.; Nobre, F.S.; Polezel, D.A.; de Oliveira, T.B.; dos Santos, J.A.; Rodrigues, A.; Sette, L.D. Production of cold-adapted enzymes by filamentous fungi from King George Island, Antarctica. Polar Biol. 2018, 41, 2511-2521. [CrossRef]

8. Duarte, A.W.F.; dos Santos, J.A.; Vianna, M.V.; Vieira, J.M.F.; Mallagutti, V.H.; Inforsato, F.J.; Wentzel, L.C.P.; Lario, L.D.; Rodrigues, A.; Pagnocca, F.C.; et al. Cold-adapted enzymes produced by fungi from terrestrial and marine Antarctic environments. Crit. Rev. Biotechnol. 2018, 38, 600-619. [CrossRef]

9. Wang, M.; Jiang, X.; Wu, W.; Hao, Y.; Su, Y.; Cai, L.; Xiang, M.; Liu, X. Psychrophilic fungi from the world's roof. Pers. Mol. Phylogeny Evol. Fungi 2015, 34, 100-112. [CrossRef] [PubMed]

10. Cortes, A.J.; Garzon, L.N.; Valencia, J.B.; Madrinan, S. On the causes of rapid diversification in the paramos: Isolation by ecology and genomic divergence in espeletia. Front. Plant Sci. 2018, 9, 1700. [CrossRef] [PubMed] 
11. Avellaneda-Torres, L.M.; Pulido, C.P.G.; Rojas, E.T. Assessment of cellulolytic microorganisms in soils of Nevados Park, Colombia. Braz. J. Microbiol. 2014, 45, 1211-1220. [CrossRef] [PubMed]

12. Landinez-Torres, A.Y.; Becerra Abril, J.L.; Tosi, S.; Nicola, L. Soil microfungi of the colombian natural regions. Int. J. Environ. Res. Public Health 2020, 17, 8311. [CrossRef] [PubMed]

13. Gualdrón-Arenas, C.; Suárez-Navarro, A.L.; Valencia-Zapata, H. Hongos del suelo aislados de zonas de vegetacion natural del paramo de chisaca, colombia. Caldasia 1997, 19, 235-245.

14. Pinos León, A.J. Exploring the Microbiome Composition of the Rhizosphere Associated with the Wild Andean Blueberry (Vaccinium Floribundum, Kunth) in the Highlands of Ecuador. Master's Thesis, Universidad San Francisco de Quito, Quito, Ecuador, 2020. Available online: https:/ / repositorio.usfq.edu.ec/bitstream/23000/9113/1/141011.pdf (accessed on 5 December 2021).

15. Kuddus, M.; Roohi Arif, J.; Ramteke, P. An overview of cold-active microbial $\alpha$-amylase: Adaptation strategies and biotechnological potentials. Biotechnology 2011, 10, 246-258. [CrossRef]

16. Santiago, M.; Ramírez-Sarmiento, C.A.; Zamora, R.A.; Parra, L.P. Discovery, Molecular Mechanisms, and Industrial Applications of Cold-Active Enzymes. Front Microbiol. 2016, 7, 1408. [CrossRef]

17. Kumar, A.; Mukhia, S.; Kumar, R. Industrial applications of cold-adapted enzymes: Challenges, innovations and future perspective. 3 Biotech 2021, 11, 426. [CrossRef] [PubMed]

18. de Oliveira, T.B.; de Lucas, R.C.; de Almeida Scarcella, A.S.; Pasin, T.M.; Contato, A.G.; Polizeli, M.L.T.M. Cold-active lytic enzymes and their applicability in the biocontrol of postharvest fungal pathogens. J. Agric. Food Chem. 2020, 68, 6461-6463. [CrossRef]

19. Gerday, C.; Aittaleb, M.; Bentahir, M.; Chessa, J.-P.; Claverie, P.; Collins, T.; D'Amico, S.; Dumont, J.; Garsoux, G.; Georlette, D.; et al. Cold-adapted enzymes: From fundamentals to biotechnology. Trends Biotechnol. 2000, 18, $103-107$. [CrossRef]

20. Niñerola, A.; Ferrer-Rullan, R.; Vidal-Suñé, A. Climate change mitigation: Application of management production philosophies for energy saving in industrial processes. Sustainability 2020, 12, 717. [CrossRef]

21. Andlar, M.; Rezić, T.; Marđetko, N.; Kracher, D.; Ludwig, R.; Šantek, B. Lignocellulose degradation: An overview of fungi and fungal enzymes involved in lignocellulose degradation. Eng. Life Sci. 2018, 18, 768-778. [CrossRef]

22. Pasin, T.M.; Scarcella, A.S.A.; de Oliveira, T.B.; Lucas, R.C.; Cereia, M.; Betini, J.H.A.; Polizeli, M.L.T.M. Paper industry wastes as carbon sources for Aspergillus species cultivation and production of an enzymatic cocktail for biotechnological applications. Ind. Biotechnol. 2020, 16, 56-60. [CrossRef]

23. Duncan, S.M.; Farrell, R.L.; Thwaites, J.M.; Held, B.W.; Arenz, B.E.; Jurgens, J.A.; Blanchette, R.A. Endoglucanase-producing fungi isolated from Cape Evans historic expedition hut on Ross Island, Antarctica. Environ. Microbiol. 2006, 8, 1212-1219. [CrossRef] [PubMed]

24. Polizeli, M.L.T.M.; Rizzatti, A.C.S.; Monti, R.; Terenzi, H.F.; Jorge, J.A.; Amorim, D.S. Xylanases from fungi: Properties and industrial applications. Appl. Microbiol. Biotechnol. 2005, 67, 577-591. [CrossRef] [PubMed]

25. Miri, S.; Naghdi, M.; Rouissi, T.; Kaur Brar, S.; Martel, R. Recent biotechnological advances in petroleum hydrocarbons degradation under cold climate conditions: A review. Crit. Rev. Environ. Sci. Technol. 2019, 49, 553-586. [CrossRef]

26. Jiang, G.; Chen, P.; Bao, Y.; Wang, X.; Yang, T.; Mei, X.; Banerjee, S.; Wei, Z.; Xu, Y.; Shen, Q. Isolation of a novel psychrotrophic fungus for efficient low-temperature composting. Bioresour. Technol. 2021, 331, 125049. [CrossRef]

27. Adhikari, P.; Jain, R.; Sharma, A.; Pandey, A. Plant Growth Promotion at Low Temperature by Phosphate-Solubilizing Pseudomonas spp. Isolated from High-Altitude Himalayan Soil. Microb. Ecol. 2021. [CrossRef]

28. Geoportal Ecuador-Infraestructura de Datos Espaciales. Available online: http://www.geoportaligm.gob.ec/portal/ (accessed on 19 October 2021).

29. White, T.J.; Bruns, T.; Lee, S.; Taylor, J.W. Amplification and Direct Sequencing of Fungal Ribosomal RNA Genes for Phylogenetics; Academic Press, Inc.: New York, NY, USA, 1990; pp. 315-322.

30. Hall, T. BioEdit: A user-friendly biological sequence alignment editor and analysis program for Windows 95/98/NT. Nucleic Acids Symp. Ser. 1999, 41, 95-98.

31. Thompson, J.D.; Higgins, D.G.; Gibson, T.J. CLUSTAL W: Improving the sensitivity of progressive multiple sequence alignment through sequence weighting, position-specific gap penalties and weight matrix choice. Nucleic Acids Res. 1994, 22, 4673-4680. [CrossRef] [PubMed]

32. Kumar, S.; Stecher, G.; Tamura, K. MEGA7: Molecular Evolutionary Genetics Analysis Version 7.0 for Bigger Datasets. Mol. Biol. Evol. 2016, 33, 1870-1874. [CrossRef]

33. Miller, G.L. Use of dinitrosalicylic acid reagent for determination of reducing sugar. Anal. Chem. 1959, 31, 426-428. [CrossRef]

34. Contato, A.G.; de Oliveira, T.B.; Aranha, G.M.; de Freitas, E.N.; Vici, A.C.; Nogueira, K.M.V.; de Lucas, R.C.; de Almeida Scarcella, A.S.; Buckeridge, M.S.; Silva, R.N.; et al. Prospection of fungal lignocellulolytic enzymes produced from jatoba (Hymenaea courbaril) and tamarind (Tamarindus indica) seeds: Scaling for bioreactor and saccharification profile of sugarcane bagasse. Microorganisms 2021, 9, 533. [CrossRef] [PubMed]

35. Garen, A.; Siddiqi, O. Suppression of mutations in the alkaline phosphatase structural cistron of E. coli. Proc. Natl. Acad. Sci. USA 1962, 48, 1121-1127. [CrossRef] 
36. Kersters-Hilderson, H.; Claeyssens, M.; Van Doorslaer, E.; Saman, E.; De Bruyne, C.K. $\beta$-D-xylosidase from Baccilus pumilus. In Methods in Enzymology; Complex Carbohydrates Part D; Academic Press: Cambridge, MA, USA, 1982; Volume 83, pp. 631-639. Available online: https:/ / www.sciencedirect.com/science/article/pii/0076687982830620 (accessed on 19 August 2021).

37. Hribljan, J.A.; Suarez, E.; Heckman, K.A.; Lilleskov, E.A.; Chimner, R.A. Peatland carbon stocks and accumulation rates in the Ecuadorian paramo. Wetl. Ecol. Manag. 2016, 24, 113-127. [CrossRef]

38. Roa García, C.; Brown, S.; Krzic, M.; Lavkulich, L.; Roa-García, M.C. Relationship of soil water retention characteristics and soil properties: A case study from the Colombian Andes. Can. J. Soil Sci. 2021, 101, 147-156. [CrossRef]

39. Zúñiga-Silgado, D.; Rivera-Leyva, J.C.; Coleman, J.J.; Sánchez-Reyez, A.; Valencia-Díaz, S.; Serrano, M.; de-Bashan, L.E.; Folch-Mallol, J.L. Soil type affects organic acid production and phosphorus solubilization efficiency mediated by several native fungal strains from Mexico. Microorganisms 2020, 8, 1337. [CrossRef] [PubMed]

40. Rowley, M.C.; Grand, S.; Verrecchia, E.P. Calcium-mediated stabilisation of soil organic carbon. Biogeochemistry 2018, 137, 27-49. [CrossRef]

41. Opfergelt, S.; Georg, R.B.; Delvaux, B.; Cabidoche, Y.-M.; Burton, K.W.; Halliday, A.N. Mechanisms of magnesium isotope fractionation in volcanic soil weathering sequences, Guadeloupe. Earth Planet Sci. Lett. 2012, 341, 176-185. [CrossRef]

42. Rahimi, H.; Pazira, E.; Tajik, F. Effect of soil organic matter, electrical conductivity and sodium adsorption ratio on tensile strength of aggregates. Soil Tillage Res. 2000, 54, 145-153. [CrossRef]

43. Ishiguro, M.; Makino, T. Sulfate adsorption on a volcanic ash soil (allophanic Andisol) under low pH conditions. Colloids Surf.-Physicochem. Eng. Asp. 2011, 384, 121-125. [CrossRef]

44. Hazelton, P.; Murphy, B. Interpreting Soil Test Results: What Do All the Numbers Mean? Csiro Publishing: Clayton, Australia, 2016; p. 201.

45. Motsara, M.R.; Roy, R.N. Guide to Laboratory Establishment for Plant Nutrient Analysis. FAO Fertilizer and Plant Nutrition Bulletin; Food and Agriculture Organization of the United Nations: Rome, Italy, 2008; p. 219.

46. Sembiring, M. Bacterial and fungi phosphate solubilization effect to increase nutrient uptake and potatoes (Solanum tuberosum L.) production on Andisol Sinabung area. J. Agron. 2017, 16, 131-137. [CrossRef]

47. Bensch, K.; Braun, U.; Groenewald, J.Z.; Crous, P.W. The genus Cladosporium. Stud. Mycol. 2012, 72, 1-401. [CrossRef]

48. Del-Cid, A.; Ubilla, P.; Ravanal, M.-C.; Medina, E.; Vaca, I.; Levicán, G.; Eyzaguirre, J.; Chávez, R. Cold-active xylanase produced by fungi associated with Antarctic marine sponges. Appl. Biochem. Biotechnol. 2014, 172, 524-532. [CrossRef]

49. Wang, X.; Wu, X.; Jiang, S.; Yin, Q.; Li, D.; Wang, Y.; Wang, D.; Chen, Z. Whole genome sequence and gene annotation resource for Didymella bellidis associated with tea leaf spot. Plant Dis. 2021, 105, 1168-1170. [CrossRef]

50. Zhang, J.; Bruton, B.D.; Biles, C.L. Cell wall-degrading enzymes of Didymella bryoniae in relation to fungal growth and virulence in cantaloupe fruit. Eur. J. Plant Pathol. 2014, 139, 749-761. [CrossRef]

51. Rafiq, M.; Nadeem, S.; Hassan, N.; Hayat, M.; Sajjad, W.; Zada, S.; Sajjad, W.; Hasan, F. Fungal recovery and characterization from Hindu Kush mountain range, Tirich Mir glacier, and their potential for biotechnological applications. J. Basic Microbiol. 2020, 60, 444-457. [CrossRef]

52. Hassan, N.; Hasan, F.; Nadeem, S.; Hayat, M.; All, P.; Khan, M.; Sajjad, W.; Zada, S.; Rafiq, M. Community analysis and characterization of fungi from Batura Glacier, Karakoram Mountain Range, Pakistan. Appl. Ecol. Environ. Res. 2018, 16, 5323-5341. [CrossRef]

53. Pacelli, C.; Bryan, R.A.; Onofri, S.; Selbmann, L.; Shuryak, I.; Dadachova, E. Melanin is effective in protecting fast and slow growing fungi from various types of ionizing radiation. Environ. Microbiol. 2017, 19, 1612-1624. [CrossRef] [PubMed]

54. Dadachova, E.; Casadevall, A. Ionizing radiation: How fungi cope, adapt, and exploit with the help of melanin. Curr. Opin. Microbiol. 2008, 11, 525-531. [CrossRef] [PubMed]

55. Ravikumar, R. Effect of transport phenomena of Cladosporium cladosporioides on decolorization and chemical oxygen demand of distillery spent wash. Int. J. Environ. Sci. Technol. 2015, 12, 1581-1590. [CrossRef]

56. Mohan Kumar, N.S.; Ramasamy, R.; Manonmani, H.K. Production and optimization of l-asparaginase from Cladosporium sp. using agricultural residues in solid state fermentation. Ind. Crops Prod. 2013, 43, 150-158. [CrossRef]

57. Quintanilla, D.; Hagemann, T.; Hansen, K.; Gernaey, K.V. Fungal morphology in industrial enzyme production-modelling and monitoring. In Filaments in Bioprocesses; Krull, R., Bley, T., Eds.; Springer: Berlin/Heidelberg, Germany, 2015; pp. 29-54. Available online: https://www.webofscience.com/wos/woscc/full-record/WOS:000365169300003 (accessed on 19 October 2021).

58. Abrha, B.; Gashe, B.A. Cellulase production and activity in a species of Cladosporium. World J. Microbiol. Biotechnol. 1992, 8, 164-166. [CrossRef] [PubMed]

59. Maya-Yescas, M.E.; Revah, S.; Le Borgne, S.; Valenzuela, J.; Palacios-González, E.; Terrés-Rojas, E.; Vigueras-Ramírez, G. Growth of Leucoagaricus gongylophorus Möller (Singer) and production of key enzymes in submerged and solid-state cultures with lignocellulosic substrates. Biotechnol. Lett. 2021, 43, 845-854. [CrossRef]

60. Peñalva, M.A.; Arst, H.N. Regulation of gene expression by ambient ph in filamentous fungi and yeasts. Microbiol. Mol. Biol. Rev. 2002, 66, 426-446. [CrossRef]

61. Zucconi, L.; Canini, F.; Temporiti, M.E.; Tosi, S. Extracellular enzymes and bioactive compounds from Antarctic terrestrial fungi for bioprospecting. Int. J. Environ. Res. Public Health 2020, 17, 6459. [CrossRef] [PubMed]

62. Hassan, N.; Rafiq, M.; Hayat, M.; Nadeem, S.; Shah, A.A.; Hasan, F. Potential of psychrotrophic fungi isolated from siachen glacier, Pakistan, to produce antimicrobial metabolites. Appl. Ecol. Environ. Res. 2017, 15, 1157-1171. [CrossRef] 
63. Grujic, M.; Dojnov, B.; Potocnik, I.; Atanasova, L.; Duduk, B.; Srebotnik, E.; Druzhinina, I.S.; Kubicek, C.P.; Vujčić, Z. Superior cellulolytic activity of Trichoderma guizhouense on raw wheat straw. World J. Microbiol. Biotechnol. 2019, 35, 194. [CrossRef]

64. Ghazali, M.F.S.M.; Zainudin, N.A.I.M.; Abd Aziz, N.A.; Mustafa, M. Screening of lignocellulolytic fungi for hydrolyzation of lignocellulosic materials in paddy straw for bioethanol production. Malays. J. Microbiol. 2019, 15, 379-386.

65. Ji, L.; Yang, J.; Fan, H.; Yang, Y.; Li, B.; Yu, X.; Zhu, N.; Yuan, H. Synergy of crude enzyme cocktail from cold-adapted Cladosporium cladosporioides Ch2-2 with commercial xylanase achieving high sugars yield at low cost. Biotechnol. Biofuels 2014, 7, 130. [CrossRef]

66. Aslam, M.S.; Aishy, A.; Samra, Z.Q.; Gull, I.; Athar, M.A. Identification, Purification and characterization of a novel extracellular laccase from Cladosporium cladosporioides. Biotechnol. Biotechnol. Equip. 2012, 26, 3345-3350. [CrossRef]

67. Halaburgi, V.M.; Sharma, S.; Sinha, M.; Singh, T.P.; Karegoudar, T.B. Purification and characterization of a thermostable laccase from the ascomycetes Cladosporium cladosporioides and its applications. Process Biochem. 2011, 46, 1146-1152. [CrossRef]

68. Gawas-Sakhalkar, P.; Singh, S.M.; Naik, S.; Ravindra, R. High-temperature optima phosphatases from the cold-tolerant Arctic fungus Penicillium citrinum. Polar Res. 2012, 31, 11105. [CrossRef]

69. Krishnan, A.; Convey, P.; Gonzalez-Rocha, G.; Alias, S.A. Production of extracellular hydrolase enzymes by fungi from King George Island. Polar Biol. 2016, 39, 65-76. [CrossRef]

70. Fenice, M.; Selbmann, L.; Zucconi, L.; Onofri, S. Production of extracellular enzymes by Antarctic fungal strains. Polar Biol. 1997, 17, 275-280. [CrossRef]

71. Wang, N.; Zang, J.; Ming, K.; Liu, Y.; Wu, Z.; Ding, H. Production of cold-adapted cellulase by Verticillium sp. isolated from Antarctic soils. Electron. J. Biotechnol. 2013, 16, 10. Available online: http://www.ejbiotechnology.info/index.php/ ejbiotechnology/article/view / 1302 (accessed on 9 December 2021). [CrossRef]

72. Salunke, M.; Sondge, D.B.; Yadav, S.; Warkhade, R.; Rathod, S.; Kate, S. Alkaline phosphatase production by Enterobacter hormaechei isolated from birds fecal waste and its optimization. Int. J. Adv. Sci. Technol. 2020, 29, 9. 